\title{
THE IMPACT OF INDONESIAN FILM TOWARDS PROMOTING RANU KUMBOLO LAKE IN EAST JAVA, INDONESIA CASE STUDY: '5 CM MOVIE'
}

\section{Jessica Hoorina}

Swiss German University, Tangerang, Indonesia

Email: jhoorina@live.com

\section{Vishnuvardhana S. \\ Soeprapto, BA, MA}

Swiss German University, Tangerang, Indonesia

Email: vishnuvardhana.soeprapto@sgu.ac.id

A phenomenon called film-induced tourism which lately been increasing the amount of visitor towards a destination that appear through a movie. Watching movie is an intangible visual experience, but it could be change into an actual experience by visiting the film locations. It will give tourist an involvement and recreate their own feeling by experiencing themselves into a destination. In this research, evaluate the correlation of film-induced tourism towards the effectiveness of promotional destination tool. By using a novel-based movie from Indonesia, ' 5 Cm' movie and Ranu Kumbolo Lake, which is located in Mount Semeru in East Java, Indonesia; as the location which will be promoted as the result of watching ' $5 \mathrm{Cm}$ ' movie. The research methods will be using quantitative data and also questionnaires as research techniques. This research shows a strong relationship between film-induced tourism and the effectiveness of promotional destination tool, which shown by Structural Equation Modeling (SEM).

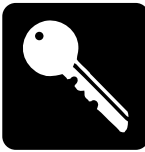

Film-induced Tourism, Promotion Tool, Destination Image 


\section{INTRODUCTION I.I Background}

Tourism is defined as the activity of people travelling and staying in a destination outside their common atmosphere for leisure, business or other purposes (go2, 2014). In other words, it is the business of attracting tourists and giving them accommodation and entertainment (Figueroa, 2014). Tourists are people who take a trip for pleasure or culture, going to places to fulfill their curiosity (Figueroa, 2014).

In most cases, creating a place to become a destination to where people can travel, stay, and do for leisure, business and other activities, does not happen magically. It requires an attraction to draw attention. Tourist attractions could be described as the main purpose for tourism. A "tourist attraction" is a place that domestic and foreign tourists are visit, that have so many features, such as cultural heritage, natural wonders, unusual sites (e.g. skyscrapers), supernatural events (e.g. UFOs), and many others (Kruczek, 2010).

This study, it will discuss about natural wonders, specifically lake. Lakes are smaller than seas, usually fresh and mostly or fully encircled by land. They often feature resorts and recreation facilities (Mancini, 2010). There are so many lakes in Indonesia and one particularly beautiful lake is Ranu Kumbolo. Ranu Kumbolo is located on Mount Semeru, East Java, Indonesia. It covers 8 hectares and is 2390 meters above sea levels. This lake is a place refuge, where Mount Semeru climbers use as a resting place (Kompas. Com, 2013). Due to the movie '5 Cm', which used this lake as its location, Ranu Kumbolo lake has become more popular among tourists (Law, 2013).
Supposedly, destinations are promoted using one or a mixture of promotional tools (advertising, personal selling, sales promotion, publicity, public relations and the internet) (Esu, Promoting an Emerging Tourism Destination, 2010). In this case, a destination was promoted through film production, which is a new technique and tools to introduce a destination (Fikri, 2013). For instance, the trilogy of "Lord of the Rings" promoting New Zealand (Vagionis \& Loumioti, 2011; Fikri, 2013; Kraaijenzank, 2009) and the Indonesian film, "Laskar Pelangi" promoted East Belitung, Sumatera, Indonesia as a destination for domestic tourists (Antara, 2014).

Films are a great media to introduce new perceptions, by making the old information by confirming new information. (Tanskanen, 2012). The growth of international travel and the development of the entertainment industry have affected the growth of film tourism. This phenomenon should be considered as a major tourism marketing strategy (Tanskanen, 2012). One example, as previously mentioned is a famous Indonesian novel-based movie '5 Cm' which used Ranu Kumbolo Lake as its location. This movie has inspired domestic tourist to visit this lake and put themselves into the movie experience.

Due to this phenomenon, called filminduced tourism, means that there has been increasing the amount of visitor towards a destination through films. The film makers are searching for good locations in natural or urban environment, which are fit for filming. In addition, the location must be natural, pleasant or unique. Those reasons could make the viewer willing to go to the destination (Beric, Kovacevic, Simat, \& Bozic, 2013).

Watching movie is an intangible visual 
experience, but it could be change into an actual experience by visiting the film locations. It will give tourist an involvement and recreate their own feeling by experiencing themselves into a destination. That is why film locations are really affecting to tourists (Blaha, 2012). In this research, we could examine how do these phenomenon's impact to the benefits of promoting Ranu Kumbolo Lake.

\section{I.II Research Problems}

From this study, there is one problem to be discovered:

Film induced tourism '5 Cm' movie possibly has a significant influence towards promoting Ranu Kumbolo Lake.

\section{I.III Research Questions}

There is one main question for this study:

Q1: How significant does film induced tourism ' $5 \mathrm{Cm}$ ' movie towards promoting Ranu Kumbolo Lake?

\section{I.IV Research Objectives}

This study has one main objective:

- $\quad$ To analyze the influence of film induced tourism '5 Cm' movie towards promoting Ranu Kumbolo Lake.

\section{I.V Significance Of Study}

This study is significant for two reasons:

- $\quad$ First, the relation between the ' 5 $\mathrm{Cm}$ ' movie become a tool of promotion for Ranu Kumbolo Lake. Its purpose to introducing the existence and increasing the amount of tourist of Ranu Kumbolo Lake among the peoples.

- $\quad$ Second, this study might be for a further research for the future in creating a new way to promoting tourism destination through film.

\section{LITERATURE STUDY II.I Film-Induced Tourism}

The latest phenomenon that had been increased over past 25 years called FilmInduced Tourism, mostly caused by the growth the influence of the media and travelling (Blaha, 2012). Film-induced tourism has also been mentioned in the international bibliography with the name "film-tourism" or "movie induced tourism" or "cinematographic tourism" (Vagionis \& Loumioti, 2011).

Describing movie-induced tourism: With movies, people are sometimes induced to go to that place which seen on the screen. An icon be eligible the 'sight' of the look from others, then the properties of a movie location -whether scenic, historical, or literary- and straight at features which are extraordinary for tourists. That is why, in the significance that peoples are looking for sights that seen on the screen, they turn out to be movie-induced tourists (Kezban, 2013).

A phenomenon named film-tourism could be defined as some visitors who visit a destination because appearing on cinema screen (Kezban, 2013) . As a result, increasing amount of visitors to a destination which is cause from its present in a movie either in a cinema, video, Digital Video Disc (DVD), or in an internet (Kezban, 2013). From previous research from Tooke and Baker (Kezban, 2013 ) there is an enormous $93 \%$ growing of an amount of visitors to the destination which are used in a film shooting. Another shocking effect of films on tourism: a long-term grow up to $96 \%$ in amount of tourist in a film location until five years after first screening, illustrated by Riley, 
Baker and Van Doren (Kezban, 2013).

Those are examples of movies which generated increasing amount of visitor:

\begin{tabular}{|c|c|c|}
\hline Movie & Location & $\begin{array}{l}\text { Impact on Visitor Numbers } \\
\text { or Tourist Revenue }\end{array}$ \\
\hline Braveheart & $\begin{array}{l}\text { Wallace } \\
\text { Monument, } \\
\text { Scotland }\end{array}$ & $\begin{array}{l}300 \% \text { increase of visitors in } \\
\text { year after release }\end{array}$ \\
\hline $\begin{array}{l}\text { Mission } \\
\text { Impossible } \\
2\end{array}$ & $\begin{array}{l}\text { National Park } \\
\text { in Sydney }\end{array}$ & $\begin{array}{l}200 \% \text { increase of visitors } \\
\text { within four years }\end{array}$ \\
\hline $\begin{array}{l}\text { Pride and } \\
\text { Prejudice }\end{array}$ & $\begin{array}{l}\text { Lyme Park, } \\
\text { Chesire, UK }\end{array}$ & $\begin{array}{l}150 \% \text { increase of visitors in } \\
\text { year after release }\end{array}$ \\
\hline Troy & $\begin{array}{l}\text { Canakkale, } \\
\text { Turkey }\end{array}$ & $\begin{array}{l}73 \% \text { increase of visitors in } \\
\text { year after release }\end{array}$ \\
\hline $\begin{array}{l}\text { Little } \\
\text { Woman }\end{array}$ & $\begin{array}{l}\text { Orchard House, } \\
\text { Concord, } \\
\text { Massachussets }\end{array}$ & $\begin{array}{l}65 \% \text { increase of visitors in } \\
\text { year after release }\end{array}$ \\
\hline $\begin{array}{l}\text { Harry } \\
\text { Potter }\end{array}$ & $\begin{array}{l}\text { Various } \\
\text { Locations in } \\
\text { UK }\end{array}$ & $\begin{array}{l}50 \% \text { increase in tourism in all } \\
\text { locations year after release }\end{array}$ \\
\hline $\begin{array}{l}\text { Sense and } \\
\text { Sensibility }\end{array}$ & $\begin{array}{l}\text { Saltram House, } \\
\text { England }\end{array}$ & $\begin{array}{l}39 \% \text { increase of visitors in } \\
\text { year after release }\end{array}$ \\
\hline The Beach & Thailand & $\begin{array}{l}22 \% \text { increase of youth market } \\
\text { in year after release }\end{array}$ \\
\hline $\begin{array}{l}\text { Four } \\
\text { Weddings } \\
\text { and a } \\
\text { Funeral }\end{array}$ & $\begin{array}{l}\text { The Crown } \\
\text { Hotel, } \\
\text { Amersham, } \\
\text { England }\end{array}$ & $\begin{array}{l}\text { Fully Booked for at least } \\
\text { three years after release }\end{array}$ \\
\hline $\begin{array}{l}\text { Notting } \\
\text { Hill }\end{array}$ & $\begin{array}{l}\text { Kenwood } \\
\text { House, England }\end{array}$ & $\begin{array}{l}10 \% \text { of visitors one month } \\
\text { after release }\end{array}$ \\
\hline
\end{tabular}

Table 1: Impacts of Film-Induced Tourism Source: (Kezban, 2013).

\section{II.I.I Destination Image}

Image is crucial, it has to be right, without it, a destination will be nothing. Having a great image is vital to attract visitors. In this case will focusing on how a destination image will be created after being featured on a film or cinema screen. Therefore, image formation process is the key factor to keep in mind, related in how image is noticed and the function for the destination (Kraaijenzank, 2009).

One of the main objects to motivate visitors to go to a location is the potential that these peoples want to experiencing a different live from their live from their home location. This potential is encouraged with tourism attraction practices such as films, television, literature, magazines and videos (Vagionis \& Loumioti, 2011). According to Schofield, modern tourists structure 'destination images' through using films and movies in television, with no influences are including a promotional material (Vagionis \& Loumioti, 2011). Another suggestion from Morgan and Pritchard, that a destination position in a film is the crucial point in a tourism product position (Vagionis \& Loumioti, 2011). At last, based on Russell, that destination position in a setting of a film and as a result of being seen to the viewers is very useful towards promotional process for a destination (Vagionis \& Loumioti, 2011).

These are following seven stage theory of formation destination image (Jesus, 2013):

1. Accumulation of mental images about vacation experiences

2. Modifications of those images by further information

\section{Decision to take a vacation trip}

4. Travel to the destination

5. Participation at the destination

6. Return home

7. Modification of images based on experience

In image formations there are two factors that important; pull and push factors. In a simple word, defining those factors could be like this: A tourist himself makes the push factors by willing to escape their routine activity and the destinations will be the 'pull' factors. The potential visitors who would like to go to the destination, is proposed by the image which release from the tourism official. For that reason, developing a great destination is become an important concern to make a 'pull' to 
attract visitors (Kraaijenzank, 2009).

\section{II.I.I Movie Location}

Location and film experiences are increased memories by combining them with other factors, such as actors, events, and setting (Rewtrakunphaiboon, 2009). For the reason, films' watcher can be induced by physical properties, such as scenery and landscape and also their related with the theme, storylines, events and actors, it could be determining the watcher' feelings, emotions and attitudes about the places or locations. An iconic attraction which born from those aspects such as locations, events, and characters has been donate such a powerful values in a film narrations. There is a review about the difference about forms and characteristics that will be shown in the table below (Rewtrakunphaiboon, 2009):

\section{Form Characteristics}

1. Film-induced tourism as part of a main holiday Tourists will visit film location or book a film tour for a holiday without any previous destination knowledge

2. Film-induced tourism as a main purpose out of special interest The booking of a holiday to a destination as a result of its profiles on the screen

3. Film-induced tourism icons as focal points of visit Natural beauty, historical places, actors can serve as icons

4. Film-induced tourism to places where filming is only believed to have taken place Tourists visit the filming places even if the film represents a different setting.

5. Film-induced tourism as part of romantic gaze Tourists like to gaze on places reinforced by the films in solitude, establishing a semi-spiritual relationship with the place

6. Film-induced tourism for reasons of escape Visiting film locations elevates tourists beyond the mundane reality of everyday life

\begin{tabular}{|c|c|}
\hline Form & Characteristics \\
\hline $\begin{array}{l}\text { 1. Film-induced } \\
\text { tourism as part of a } \\
\text { main holiday }\end{array}$ & $\begin{array}{l}\text { Tourists will visit film location } \\
\text { or book a film tour for a } \\
\text { holiday without any previous } \\
\text { destination knowledge }\end{array}$ \\
\hline $\begin{array}{l}\text { 2. Film-induced } \\
\text { tourism as a main } \\
\text { purpose out of } \\
\text { special interest }\end{array}$ & $\begin{array}{l}\text { The booking of a holiday to a } \\
\text { destination as a result of its } \\
\text { profiles on the screen }\end{array}$ \\
\hline $\begin{array}{l}\text { 3. Film-induced } \\
\text { tourism icons as } \\
\text { focal points of visit }\end{array}$ & $\begin{array}{l}\text { Natural beauty, historical } \\
\text { places, actors can serve as } \\
\text { icons }\end{array}$ \\
\hline $\begin{array}{l}\text { 4. Film-induced } \\
\text { tourism to places } \\
\text { where filming is } \\
\text { only believed to } \\
\text { have taken place }\end{array}$ & $\begin{array}{l}\text { Tourists visit the filming } \\
\text { places even if the film } \\
\text { represents a different setting. }\end{array}$ \\
\hline $\begin{array}{l}\text { 5. Film-induced } \\
\text { tourism as part of } \\
\text { romantic gaze }\end{array}$ & $\begin{array}{l}\text { Tourists like to gaze on places } \\
\text { reinforced by the films in } \\
\text { solitude, establishing a semi- } \\
\text { spiritual relationship with the } \\
\text { place }\end{array}$ \\
\hline $\begin{array}{l}\text { 6. Film-induced } \\
\text { tourism for reasons } \\
\text { of escape }\end{array}$ & $\begin{array}{l}\text { Visiting film locations elevates } \\
\text { tourists beyond the mundane } \\
\text { reality of everyday life }\end{array}$ \\
\hline
\end{tabular}

Several film locations all around the world have become the pull factors for tourists to visit those particular locations. For instance, the American soap opera 'Sex and the City' movie was being a best-seller, not only in United State but in all over the world. Many restaurants, bars, and shops that appeared in the movie have become must-see destinations in New York (Rewtrakunphaiboon, 2009). Particular films could be more booming that others in magnetizing an amount of tourists to the shown destinations, which requires numerous of critical factors effecting film-induced tourism. One of the critical factor variable is the exact beauties in the setting of the film locations, can bring a strong effect on prospective tourists (Rewtrakunphaiboon, 2009). 


\section{II.II Measuring Effectiveness Of Destination Promotional Tool}

Promotion is a communicative activity of marketing (Esu \& Ebitu, 2010). Promotional activities must be exactly the same with the requirements of the tourists and combine with the other aspects in marketing mix (Esu \& Ebitu, 2010).

\section{Marketing Mix}

Marketing mix is the critical elements that conclude demand for a business or destination product (Weaver \& Lawton, 2010). The popular one from numerous marketing mix formations is $8 \mathrm{P}$ model; product, people, packaging, programming, place or distribution mix, promotion, partnership and pricing (Weaver \& Lawton, 2010)

Based on theory, a destination could be promoted through one or a mixture of promotional tools (Esu \& Ebitu, 2010). This promotional tools activities are started by individual or organizations who wanted publish the destination to the market area. For particular strategies for the promotion tourism destination require to have supports for shaping the tourism destination. This complication stated that traditional promotional tools are incompetent to produce a suitable costumer without a broad strategic approach (Esu \& Ebitu, 2010). There are the five traditional promotional tools (Esu \& Ebitu, Promoting an Emerging Tourism Destination, 2010):

\section{1) Advertising}

Advertising is several paid appearance about an organization, product, service, or idea by a well-known sponsor of nonpersonal communications.

\section{2) Public Relations}

Public Relations have a communication function, which is keeping the mutual understanding between an organization and the public.

\section{3) Sales Promotion}

Sales Promotion described as providing additional value on the sales force, distributors, or the ultimate consumer and encourages short-term sales.

\section{4) Personal Selling}

Personal Selling is a face to face communication which the seller persuades the customers to buy the company's product, service, or idea.

\section{5) Publicity}

Publicity is a non-personal communication of an organization, product, service, or idea, but not being paid for sponsorship for creating sales directly.

The evaluation of the effectiveness could be effected in two aspects, the first one is on the perception of tourists at the causing areas and the second is the effect at the obtaining area, which are the number of visitor arrivals, tourist receipts, community benefit, and environment (Esu \& Ebitu, Promoting an Emerging Tourism Destination, 2010). But according to Dieudonne (2012), it is also affect the increasing awareness' tourists of a destination. The focus in this research will only on increasing awareness and visitor arrivals, also automatically become the indicator.

\section{II.II.I Increasing Awareness}

Basically promoting destinations mean the enlargement of communicating channels with stakeholders in the direction of raising awareness of customers and persuading 
them to buy or enjoy the products (Dieudonne, 2012). Through promotion, in this case promotion a destination trough film, it can shape the perception with the scenes in the particular destination.

As the result of promotion we can see that identify the increasing awareness as the key factor required by the tourism organizers. It is supposed to build a stronger competitive position and greater benefits from tourism (Government of Canada, 2013).

\section{II.II.II The Volume Of Tourists Arrival}

Most of statements from local government's agencies, tourism associations, and film companies reveal that film-induced tourism is focusing on numbers of visitors which are attracted (Beeton, 2005). The impact film-induced tourism towards volume of tourist arrival could be seen on See Table 1.

For instance, the filming of Captain Corelli's Mandolin was on the Greek Island of Cephalonia. In 2001, after the movie was released, there was an increase in amount of visitors as much as $15-20 \%$ compared to the previous year (Blaha, 2012).

\section{METHODOLOGY III.I Type And Source Of Data III.I.I Primary Data}

Primary data is collected by researcher and achieved by survey research. A research can be uses two varieties of primary data, which are qualitative primary data and quantitative primary data. But this research will be using the quantitative primary data. The questionnaire is used for quantitative primary data. Questionnaire itself is one type of collecting data using research instrument through the respondent directly or indirectly. The questionnaire is using two variables, which are filminduced tourism and the effectiveness of destination promotional tool.

\section{III.I.II Secondary Data}

Secondary data is collected from the references from authors used, for instance book and journals of film-induced tourism, journals about the effectiveness of destination promotional tools and articles from internet that connected with filminduced tourism and the effectiveness of destination promotional tools.

\section{III.II Population}

Population is an abstract from stated objects that will be analyze, which contain specific characteristics and quality. In this research, the population will be peoples who already watch ' $5 \mathrm{Cm}$ ' movie.

\section{III.III Research Instrument}

The research instruments for this research are based on two variables, which are filminduced tourism and the effectiveness of promotional destination tool with two indicators for each variable.

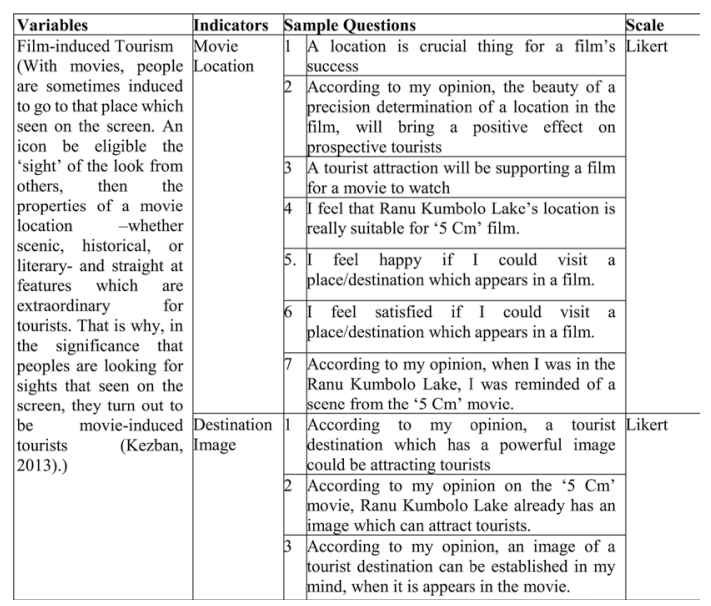




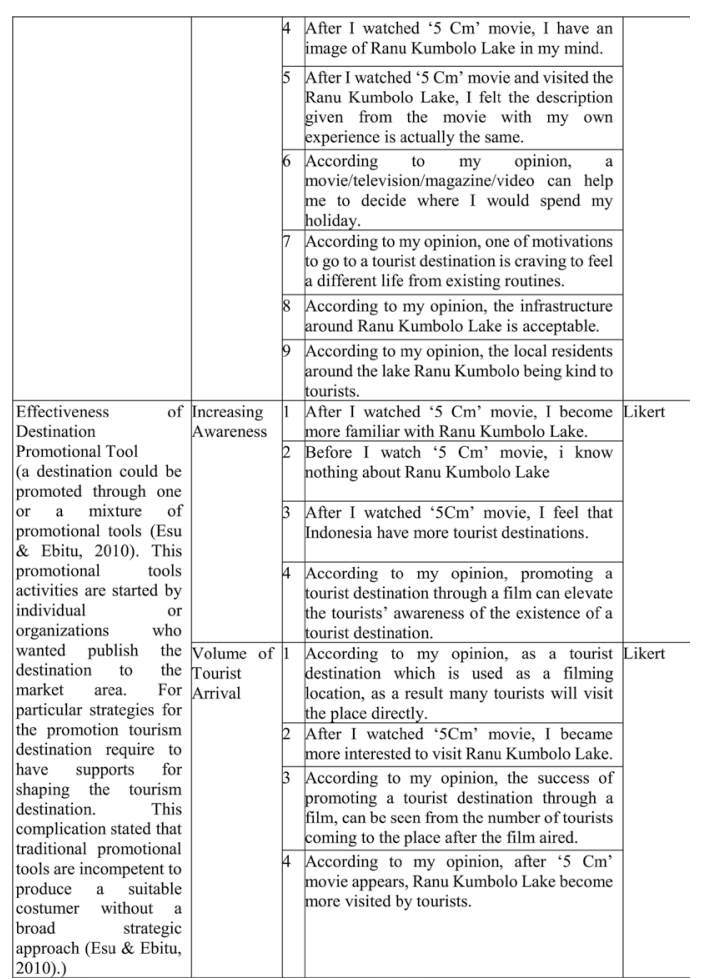

Table 3 Question Design Source: (Esu \& Ebitu, 2010; Kezban, 2013)

\section{III.IV Data Analysis III.V Data Pre-Testing}

Data pre-testing has purpose to verify several weak points in questionnaire. Data pre-testing must be completed, because it is determining which is valid or not. To resume the data collection, data pretesting must be valid.

\section{III.V.I Validity Test}

Defining validity is the power of research instrument to determine what must be determined. It measured the data collected can be used in the research. The relationship of the research aims to present can be shown from the data collection using the questionnaire. A valid questionnaire is one where the relationship to be measured is significant. The measurements of validity can be done using many methods. This research will be using KMO test using SPSS software.

\section{III.V.II Reliability Test}

Reliability is the degree estimation of the instruments is free from error (Fikri, 2013). The instruments are reliable if the answers of the respondents are consistent (Fikri, 2013). The approach taken to measure the reliability of the research instrument for pre-testing in this research will use the method of Cronbach's alpha.

\section{RESULT AND DIS- CUSSION IV.I Data Post-Testing}

\section{IV.I.I Reliability Test}

The reliability test for post-testing depends on a total of 97 respondents. From the case processing summary with $100 \%$ output validity, it occurs that the entire data are regarded as valid. From this study shows that the Cronbach's Alpha value from 97 respondents is 0.757 for the 17 research instruments. These data is regarded as reliable because the value of Cronbach's Alpha is above 0.7 .

\section{IV.I.II Validity Test}

This validity test result for data posttesting which is illustrated from 97 respondents, the result of the KaiserMeyer-Olkin Measure of Sampling Adequacy (MSA) is above 0.5. Moreover, when it is compared to the validity test of pre-testing previously, the result is get higher. The value of KMO-MSA of posttesting is 0.609 and for the significant value of Bartlett's Test of Sphericity is 0.000 . The overall data result of validity post-testing is adequate. 


\section{IV.II Data Analysis SEM MODEL}

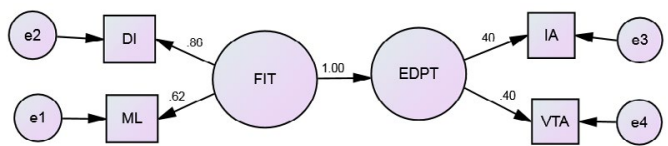

Figure 1 SEM Model - Standardized Estimates Model Source: AMOS

DI : $\quad$ Destination Image

ML : $\quad$ Movie Location

FIT $\quad$ : $\quad$ Film-Induced

Tourism

EDPT : Effectiveness of

Promotional Destination Tool

IA $\quad$ I $\quad$ I c r e a s i n g

Awareness

VTA : The Volume of Tourist Arrival

The explanation of the indicators and the relationship following based on the results of data analysis using SEM are described below:

\section{Film-Induced TourismtoEffectiveness of Promotional Destination Tool}

The relationship of 1.00 between FilmInduced Tourism and Effectiveness of Promotional Destination Tool means that $100 \%$ of Effectiveness of Promotional Destination Tool is influenced by FilmInduced Tourism. This is considered a strong relationship. Seemingly that most of tourists when it comes to the effectiveness of promotional destination tool are really influenced by a film-induced tourism itself. It means that, when a destination gets promoted, the most effective tool comes out in appearance from a film.

\section{Film-Induced Tourism}

a. Destination Image influences FilmInduced Tourism

The correlation between Destination Image and Film-Induced Tourism is at 0.86 . This is the highest value in between of the two indicators in Film-Induced Tourism. This indicates that $86 \%$ of tourists perceive the destination image very well. Based on Kraaijenzank (2009), having a great image is vital to attract visitors. In this case will focusing on how a destination image will be created after being featured on a film or cinema screen. Therefore, image formation process is the key factor to keep in mind, related in how image is noticed and the function for the destination.

\section{b. Movie Location influences Film-} Induced Tourism

The correlation between Movie Location and Film-Induced Tourism is at 0.62 . This indicates that $62 \%$ of tourists give more notice for movie location, but not as much as the previous indicator. From the previous research stated, particular films could be more booming that others in magnetizing an amount of tourists to the shown destinations, which requires numerous of critical factors effecting film-induced tourism. One of the critical factor variable is the exact beauties in the setting of the film locations, can bring a strong effect on prospective tourists (Rewtrakunphaiboon, 2009).

\section{Effectiveness of Promotional Destination Tool}

a. Increasing Awareness influences the Effectiveness of Promotional Destination Tool 
The correlation between Increasing Awareness and the Effectiveness of Promotional Destination Tool is at 0.40 . This indicates that $40 \%$ of Effectiveness of Promotional Destination Tool is affected by the Increasing Awareness. The relationship is considered as quite weak. But logically the effectiveness of promotional destination tool can be measured by the increasing of tourists' awareness.

\section{b. The Volume of Tourist Arrival influences} the Effectiveness of Promotional Destination Tool

The correlation between The Volume of Tourist Arrival and the Effectiveness of Promotional Destination Tool is at 0.40 . This indicates that $40 \%$ of Effectiveness of Promotional Destination Tool is also affected by the Volume of Tourist Arrival. This indicator has the same value with the previous indicator, therefore this is also considered as quite weak relationship. From the previous research in Chapter 2, there are various evidence that verifying about the increasing volume of tourist arrival as one of the key success of the effectiveness of promotional destination tool.

\section{IV.III Research Questions And Hypothesis Testing}

After the completion of the data analysis, now the research is going to the next phase. The table below is the research question with the following hypothesis. With the previously processed data, this question will be answered now and the following hypothesis could be accepted or rejected. The summary of the hypothesis test is in the table below:

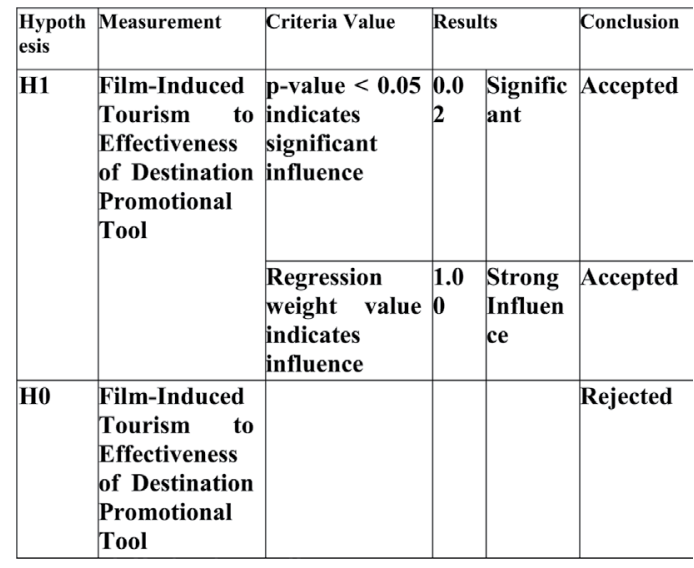

Table 12 Hypothesis Testing Sources: (Mustafa \& Wijaya, 2012)

Based on the table above, the criteria value which contain p-value and the regression weight value belong to Hypothesis 1 are considered as accepted. Because of that, the Hypothesis 0 is automatically rejected.

\section{IV.IV Research Questions And Hypothesis Testing}

Hypothesis Testing 1: Film-Induced Tourism to Effectiveness of Destination Promotional Tool

Question 1: How significant does film induced tourism "5 $\mathrm{Cm}$ " movie towards promoting Ranu Kumbolo Lake?

Hypothesis 1: There is a possibility that film induced tourism "5 Cm" movie has a significant influence towards promoting Ranu Kumbolo Lake.

From the summary result table above, the relationship of Film-Induced Tourism towards the Effectiveness of Destination Promotional Tool is revealed by the $p$-value of 0.02 . This indicates that there is influence between FilmInduced-Tourism and the Effectiveness 
of Destination Promotional Tool at $100 \%$, and the relationship is significant and accepted.

The results are fairly comparable with the previous research below:

In the previous research, according to Vagionis \& Loumioti (2011), Schofield suggests that modern tourists shape "destination images" through consumption of films and movies in television, without the prejudice that these are a promotional material. Derived from the summary of the results above, the indicator of Destination Images towards variable Film-Induced Tourism is $86 \%$.

For conclusion, the highest aspect that affecting much for Film-Induced Tourism variable is Destination Image is $86 \%$ as result from SEM model. This is similar with what the previous research from Vagionis \& Loumioti (2011)

\section{CONCLUSION AND RECOMMENDATION}

\section{V.I Conclusion}

The primary purpose in this study is to reveal the correlation between filminduced tourism and the effectiveness of destination promotional tool will be conferred further below.

\section{1) Film-induced tourism in relation to the effectiveness of promotional destination tool.}

The influence film-induced tourism towards the effectiveness of promotional destination tool is valued at $100 \%$ and regarded as significant. This shows a strong relationship between filminduced tourism and the effectiveness of promotional destination tool. It can be assumed that Ranu Kumbolo Lake which appears in ' $5 \mathrm{Cm}$ ' movie really elevating the effectiveness of promotional destination tool for the Ranu Kumbolo Lake itself.

\section{2) Film-induced Tourism in relation to the Destination Image and Movie location.}

The influence film-induce tourism towards Destination Image is valued $86 \%$ and it is regarded as significant. This shows a strong relationship between what an image created towards a destination. In this case, Ranu Kumbolo Lake has established its own image through ' $5 \mathrm{Cm}$ ' movie, which will be remembered by the viewers. Likewise the film-induced tourism towards movie location is valued $62 \%$ and also regarded as significant. This shows a quite strong relationship that a location for a film is also affect filminduced tourism. Ranu Kumbolo Lake as a film location brings a strong effect for the potential tourists.

3) Effectiveness of Promotional Destination Tool in relation to Increasing Awareness and Volume of Tourist Arrival.

The influence of the effectiveness of promotional destination tool towards Increasing Awareness and Volume of Tourist Arrival are both valued 40\% and regarded as quite weak. These two indicators are logically had a strong connectivity, when the awareness is low, as the result the volume of tourist arrival will be low also. This reason is answering why these two indicators could be at the same weak.

\section{V.2 Recommendation}


From the findings in this research, it can be recommended that:

1) For a tourism destination, a film could be considered as one of the great way to promote a tourism destination. So for film industry could start by using Indonesian tourism exposures since Indonesia has so many hidden exposures which have never been exposed.

2) For both indicators from Effectiveness of Promotional Destination Tool, it must enhance the both side of the indicators. For the increasing awareness, the best way to elevate is by increasing the other methods or ways of promotion. Besides through film, it can be from the advertisement which made by the head office of Mount Semeru that also include Ranu Kumbolo Lake and surrounding. The advertisement could be like through online/internet, newspaper, flyer or other media. Moreover, it could be from tour guide promo and familiarization trip. With all of those efforts that already mentioned above will increasing the awareness of Ranu Kumbolo Lake and automatically it will increase also the volume of tourist arrival. More tourists will then be more interested to come because they will feel know more now and at the same time also curious about Ranu Kumbolo Lake.

\section{REFERENCES}

Antara. (2014, January 10). "Wisata Laskar Pelangi Dikembangkan di Belitung Timur". Travelling.

Beeton, S. (2005). Film-Induced Tourism. Canada: Cromwell Press.

Beric, D., Kovacevic, M., Simat, K., \& Bozic, S. (2013). Film Tourism: A
COntemporary Resource for Promoting Serbia. Turizam Volume 17, Issue 1, 1819.

Blaha, D. (2012). Students' Travel Behaviour and Film Induced Tourism: Do film sets and movie locations attract young travellers? Modul Vienna University, 7.

Blaha, D. (2012). Students' Travel Behaviour and Film Induced Tourism: Do Film sets and movie locations attract young travellers? Modul Vienna University, 7.

Dieudonne, A. J. (2012). How Tour Operators Promote Mauritius As A Tourist Destination. Turku University, 11-12.

Esu, B. B. (2010). Promoting an Emerging Tourism Destination. Global Journal of Management and Business Research, 22.

Esu, B. B., \& Ebitu, E. (2010). Promoting an Emerging Tourism Destination. Global Journal of Management and Business Research, 21-27.

Figueroa, A. (2014). What is Tourims? And Why Does it Matter? About.com Tourism.

Fikri, S. (2013). Cinematographic Tourism as Modern Tool in Tourism Marketing with Case Study: 'Eat, Pray, Love' Movie. Tangerang: Swiss German University.

go2. (2014). What Is Tourism?

Government of Canada. (2013, September 5). Supporting Tourism.

Jesus, J. D. (2013). Visitor Perception of Destination Image: A Case Study of Palestinian Tourism. London Metropolitan University, 9.

Kezban, A. (2013). Film-induced Tourism in Finland Its Current State and Opportunities. Haaga-Helia University of Applied Sciences.

Kompas.Com. (2013, June 15). "Ranu 
Kumbolo Jadi Penghapus Lelah...”. News/ Travel.

Kraaijenzank, M. (2009). Movie-Induced Tourism. Aalborg University.

Kruczek, D. Z. (2010). Between Attraction and Tourist Trap - Cultural Tourism DIlemmas in the 21st Century. 2-3.

Law, D. (2013, December 11). "Cantiknya Ranu Kumbolo, Serasa Syuting 5 Cm'.

Mancini, M. (2010). Selling Destination . USA: Delmar Cengage Learning.

Morrison, A. (2010). Hospitality \& Travel Marketing 4th Edition. New York: Delmar Cengage Learning.

Mustafa, Z., \& Wijaya, T. (2012). Panduan Teknik Statistik SEM \& PLS dengan SPSS AMOS. Yogyakarta: Cahya Atma Pustaka.

Rewtrakunphaiboon, W. (2009). Film Induced Tourism: Inventing a Vacation to a Location. Boston University Academic Review.
Santoso, S. (2009). SEM, Konsep dan Aplikasinya pada AMOS. Jakarta, Indonesia: PT Elex Media Komputindo.

Tanskanen, T. (2012). Film Tourism: Study on How Films Can Be Used to Promote Tourism. Laure University of Applied Sciences, Laure Kerava, 4.

Vagionis, N., \& Loumioti, M. (2011). Movies as a Tool of Modern Tourist Marketing. Tourismos: An International Multidisciplinary Journal of Tourism.

Vagionis, N., \& Loumioti, M. (2011). Movies As A Tool Of Modern Tourist Marketing. Tourismon: An International Multidisciplinary Journal of Tourism Vol. 6 No. 2, 353-362.

Weaver, D., \& Lawton, L. (2010). Tourism Management. 4th ed. Australia: John Wiley and Sons Australia, Ltd.

Wijaya. (2009). Analisis Structural Equation Modeling Menggunakan AMOS. Yogyakarta, Indonesia: Universitas Atmajaya. 